\title{
Real-time PCR in infectious uveitis as an alternative diagnosis
}

\author{
PCR em tempo real em uveites infecciosas como um diagnóstico alternativo
}

Fabio Felipe dos Santos ${ }^{1,2}$, Alessandra Gonçalves Commodaro ${ }^{1}$, Andrea Vieira de Souza², João Renato Rebello Pinho², Roberta Sitnik², Claudio Garcia ${ }^{1}$, Ana Lúcia Pereira Ribeiro ${ }^{1}$, Cristina Muccioli ${ }^{1}$, Cláudio Luiz Lottenberg ${ }^{1,2}$, Luiz Vicente Rizzo ${ }^{2}$, Rubens Belfort Junior ${ }^{1}$

\begin{abstract}
Purpose: Uveitis is a major visual impairment disease affecting parts or the entire uveal tract and occasionally the sclera, the cornea or the optic nerve. The disease is a major cause of ocular morbidity and blindness in immunocompetent and immunocompromised patients. In this work we analyzed the sensitivity and specificity of realtime PCR to detect the etiological agent from blood, plasma, vitreous and aqueous humor and compared with the diagnostic hypothesis.

Methods: Twenty-seven patients (13 male) were studied and Real-time PCR method was used for the detection of herpes simplex virus 1 (HSV-1), herpes simplex virus 2 (HSV-2), varicella zoster virus (VZV), cytomegalovirus (CMV), Mycobacterium tuberculosis (TB) and Toxoplasma gondii (Toxo) in the aqueous humor as well as in the vitreous, blood and plasma.

Results: Our results showed the presence of Toxo, CMV, VZV or HSV-2 in 19.2\% of aqueous humor samples, and in 30\% of vitreous humor samples. In plasma and blood samples, only CMV was detected (11.1\% and 3.7\%, respectively).

Conclusion: Real-time PCR was able to detect and to confirm diagnostic hypothesis in uveitis. Our data also confirms that vitreous humor is the best source for molecular diagnosis of infectious uveitis but indicates aqueous humor samples that are easier to obtain may also be appropriate to be tested by Real-time PCR.
\end{abstract}

Keywords: Polymerase chain reaction/methods; Uveitis/diagnosis; Uveitis/microbiology; Uveitis/virology; Eye infections, viral/microbiology; Aqueous humor; Vitreous body

\section{RESUMO}

Objetivo: Uveíteéa maiorcausa de doença ocularque afeta o trato uveal, eocasionalmente a esclera, cornea e o nervo óptico. Esta doença é a maior causa de morbidade ocular e cegueira em pacientes imunocompetentes e imunossuprimidos. Neste trabalho nós analisamos a sensiblidade e especificidade do PCR em tempo real para detectar agentes etiológicos no sangue, plasma, humor vítreo e aquoso, e comparamos com a hipótese diagnóstica.

Métodos: Vinte e sete pacientes (13 homens) foram estudados e o método de PCR em tempo real foi usado para detectar o vírus da herpes simples 1 (HSV-1), vírus da herpes simples 2 (HSV-2), vírus varicella zoster (VZV), citomegalovírus (CMV), Mycobacterium tuberculosis (TB) e Toxoplama gondii (Toxo) no humor aquoso e vítreo, além do sangue e plasma.

Resultados: Nossos resultados mostraram a presença de Toxo, CMV, VZV ou HSV-2 em 19,2\% das amostras de humor aquoso, e em 30\% das amostras de humor vítreo. Nas amostras de plasma e sangue somente CMV foi detectado (11,1\% e 3,7\%, respectivamente). Conclusão: PCR em tempo real foi capaz de detectar e confirmar a hipótese diagnóstica em uveíte. Nossos dados confirmam que o humor vítreo é a melhor fonte para diagnóstico molecular de uveíte infecciosa, porém o humor aquoso também foi uma fonte importante de detecção, além de ser mais fácil de se obter.

Descritores: Reação em cadeia da polimerase/métodos, Uveíte/diagnóstico; Uveíte/ microbiologia; Uveíte/virologia; Infecções oculares virais/microbiologia; Humor aquoso; Corpo vitreo

\section{INTRODUCTION}

Uveitis is a major visual impairment disease affecting parts or the entire uveal tract (iris, ciliary body, and choroid)(1) and occasionally the sclera, the cornea or the optic nerve. Uveitis is an important cause of ocular morbidity and blindness in several countries ${ }^{(2)}$ and approximately $20 \%$ to $45 \%$ of uveitis cases are infectious ${ }^{(3)}$, potentially leading to blindness in both immunocompetent and immunocompromised patients(4).

Despite remarkable progress in treatment, clinical diagnosis of uveitis is not always precise. Thus, we investigated the role of realtime PCR samples obtained from the blood/plasma, the aqueous as well as the vitreous in its diagnosis. Indeed, real-time PCR has successfully been used to diagnose ocular toxoplasmosis ${ }^{(5,6)}$, herpes simplex virus ${ }^{(7)}$, cytomegalovirus retinitis ${ }^{(8,9)}$, and varicella-zoster virus retinitis ${ }^{(10)}$. The method has also been described as a fast technique for quantitative evaluation of ocular samples for the presence of infectious pathogens ${ }^{(3,11,12)}$.

We analyzed the sensitivity and specificity of real-time PCR to detect the etiological agent from blood, plasma, vitreous and aqueous humors and compared with the diagnostic hypothesis.

\section{METHODS}

\section{Patients}

A total of 27 patients (13 male, ranging from 20 to 60 years old) were recruited at the Department of Ophthalmology of the Federal University of São Paulo from May 2009 to October 2010. The diagnosis of uveitis was based on clinical findings according to the criteria established by the International Uveitis Study Group and the Research Committee of the American Uveitis Society ${ }^{(13)}$. Total
Submitted for publication: August 14,2011

Accepted for publication: August 24, 2011

Study carried out at the Department of Ophthalmology, Universidade Federal de São Paulo UNIFESP - São Paulo (SP), Brazil, and at Hospital Israelita Albert Einstein - HIAE - São Paulo (SP), Brazil.

${ }^{1}$ Physician, Instituto da Visão, Hospital São Paulo, Universidade Federal de São Paulo - UNIFESP São Paulo (SP), Brazil.

2 Physician, Hospital Israelita Albert Einstein - HIAE - São Paulo (SP), Brazil.Curitiba (PR), Brazil.
Funding: No specific financial support was available for this study.

Disclosure of potential conflicts of interest: F.F.dos Santos, None; A.G.Commodaro, None; A.V.de Souza, None; J.R.R.Pinho, None; R.Sitnik, None; C.Garcia, None; A.L.P.Ribeiro, None; C.Muccioli, None; C.L.Lottemberg, None; L.V.Rizzo, None; R.Belfort Jr., None.

Correspondence address: Rubens Belfort Jr. Vision Institute, Department of Ophthalmology, Federal University of São Paulo, Rua Botucatu, 820 - São Paulo (SP) - 04023-062 - Brazil.

Telephone number: 55-11-5085-2010; FAX number: 55-11-5573-4002 -

E-mail: clinbelf@uol.com.br

Institutional Review Board - IRB (Hospital Albert Einstein - Ref 09/1041 - UNIFESP - Ref 0094/09) 
number of patients and the diagnostic hypothesis as well as the presence of HIV infection are listed in table 1. The study was approved by the Institutional Review Board (IRB) (Hospital Albert Einstein CEP 09/1041; UNIFESP - CEP 0094/09) and written informed consent was obtained from all studied subjects.

\section{DNA Extraction}

Peripheral blood $(5 \mathrm{ml})$ samples were collected (BD Vacutainer) from all patients with uveitis. Subjects with indication for vitrectomy had $0.5 \mathrm{ml}$ of vitreous (20 patients) and $0.2 \mathrm{ml}$ of the aqueous humor (26 patients) collected prior to the procedure. Samples were stored at $3^{\circ} \mathrm{C}$ until extraction. DNA was extracted from the peripheral blood and the vitreous humor using QIAamp DNA Blood Midi Kit (Qiagen, Valencia, CA), and aqueous humor and plasma by QIAamp DNA Blood Micro Kit (Qiagen, Valencia, CA). Positive control T. gondii DNA was extracted from $\mathrm{RH}$ culture with $9 \times 10^{6}$ parasites $/ \mathrm{ml}$ using QIAamp DNA Blood Midi Kit (Qiagen, Valencia, CA) following the manufacturer's instructions.

\section{Real-time PCR analysis}

For T. gondii analysis, real-time PCR was performed at the Albert Einstein Hospital using primers and probe designed for the B1 gene as described by Fekkar et al.(14). Assays were performed using Taqman Universal Master Mix 2 x (Applied Biosystems ${ }^{\circledR}$, USA) to a $25 \mu$ l final reaction volume containing $0.3 \mu \mathrm{M}$ forward primer, $0.5 \mu \mathrm{M}$ reverse primer, $0.15 \mu \mathrm{M}$ fluorescent probe, and $5 \mu \mathrm{l}$ of DNA. For cytomegalovirus, tuberculosis, herpes simplex 1 and 2, and varicella zoster analysis the real-time PCR was performed according to the manufacturer's instructions (Nanogen Advanced Diagnostics, Italy). PCR was performed on an Applied Biosystems 7500 Fast Real-Time PCR System ${ }^{\circledR}$. As a negative control we replaced DNA with deionised water, and as positive control we used $4 \mu \mathrm{l}$ DNA extracted from a T. gondii RH strain culture as described above. Positive controls for the reactions involving the other pathogens were prepared using materials provided from the kit manufacturer (Nanogen Advanced Diagnostics, Italy).

\section{RESULTS}

In table 2 was observed that the number of positive samples was higher in vitreous when compared with aqueous humor. In vitreous humor samples, it was possible to detect and identify the infectious agents in 30\% of the samples (6/20) while in the aqueous it was possible to detected and identify infectious agents in $19.2 \%$ (5/26). In plasma and blood samples only CMV was detected, $11.1 \%$ $(3 / 27)$ and $3.7 \%(1 / 27)$.

As shown in table $3, T$. gondii was the most frequently detected pathogen and most commonly detected in the vitreous and aqueous in HIV patients. The patient $\mathrm{HIV}^{+}$also was positive to T. gondii in the vitreous humor. The CMV, HSV2 and VZV were found only once in the aqueous humor. Moreover, HSV1, HSV2 and VZV were found only once in the vitreous humor. None of the samples revealed TB and therefore it was unlikely that any of the patients had uveitis caused by this pathogen. Twenty two patients had one diagnostic hypothesis, while other five patients presented a combination of two diagnosis. Among these five patients, two of them (patients 6 and 18) had one of the diagnostic hypothesis confirmed, and the other three (patients 7, 23 and 26) had negative results of the two diagnostic hypothesis. Moreover, five patients had a positive PCR result for toxoplasmosis, confirming the clinical diagnosis. On the other hand, in three patients (patients 3 , 5 and 25) PCR result showed infection by a different agent that was supposed by clinical diagnostic. One of them had a clinical diagnosis of non-infectious uveitis but was infected by CMV. The other two patients with clinical diagnosis of non-infectious uveitis presented PCR negative to all pathogens analyzed in this study (Table 3).

\section{DISCUSSION}

Accurate and timely etiological diagnosis is of major importance for the management of patients with uveitis, dictating the therapeutic decision and ultimately the visual prognosis. However, patients with uveitis of infectious and non-infectious etiologies frequently share clinical signs and symptoms at presentation, representing diagnostic challenges, especially when serology is unable to establish the diagnosis.

In this work, we investigated if real-time PCR could detect the specific infectious agent in various types of samples collected from patients to help to identify the cause of uveitis. The analysis of all the samples helped us to conclude whether a given patient was likely to be affected by an infectious or non-infectious uveitis and compare the results obtained with this sensitive method with the clinical hypothesis.

This study confirmed that real-time $P C R$ was successful in detecting T. gondii, CMV, VZV, HSV-1 and HSV-2 in vitreous humor. Previous studies have shown that PCR is a useful tool for detection of cytomegalovirus, M. tuberculosis ${ }^{(15)}$, herpes simplex virus ${ }^{(15,16)}$ and $T$. gondi( ${ }^{6,17)}$ DNA in vitreous humor. Thus, because the posterior uveal tract is the most common location of infectious uveitis, vitreous humor was accordingly the best sample to detect the specific infectious agent of posteiror uveitis using real-time PCR. Moreover, T. gondii was the most frequently detected pathogen. In 2007, Westeneng and collaborators also showed T. gondii infection as the most frequently detected ${ }^{(18)}$.

CMV infections were mostly detected in plasma samples and in one case it was detected in plasma and blood. The uveitis of the other two patients with plasma positive to CMV and negative in the other samples, was probably caused by other reasons than this agent. One of the three patients was treated with corticosteroids and become prone cytomegalovirus infection and CMV retinitis usually caused in $\mathrm{HIV}^{+}$patients ${ }^{(19)}$. We had a case of clinical diagnosis of CMV and the result of real-time PCR was positive for VZV. Clinical examination leaned CMV because the patient is $\mathrm{HIV}^{+}$and these patients are suffering from recurrence of cytomegalovirus due to antiretroviral treatment, and clinical characteristics are indistinguishable from previously ${ }^{(19,20)}$.

Table 1. Clinical diagnosis

\begin{tabular}{lcc}
\hline Diagnosis & Number & (\%) \\
\hline T. gondii & 17 & 63.0 \\
M. tuberculosis & 4 & 14.8 \\
CMV & 3 & 11.1 \\
Non-infectious & 3 & 11.1 \\
HIV & 2 & 7.4 \\
HSV & 2 & 7.4 \\
Candida & 1 & 3.7 \\
Syphilis & 1 & 3.7 \\
VZV & 1 & 3.7 \\
\hline
\end{tabular}

Table 2. Positives samples to real-time PCR

\begin{tabular}{lcc}
\hline Sample & $\mathbf{N}(\%)$ & Total (\%) \\
\hline Blood & $1(3.7)$ & $27(100)$ \\
Plasma & $3(11.1)$ & $27(100)$ \\
Aqueous humor & $5(19.2)$ & $26(100)$ \\
Vitreous humor & $6(30.0)$ & $20(100)$ \\
\hline
\end{tabular}


Table 3. Correlation between diagnostic hypotesis and positive real-time PCR in samples of blood, plasma, aqueous, and vitreous humor

\begin{tabular}{|c|c|c|c|c|c|c|c|c|c|}
\hline \multirow[b]{2}{*}{ Patient \# } & \multirow[b]{2}{*}{ Diagnostic hypothesis } & \multicolumn{4}{|c|}{ HIV $^{+}$} & \multicolumn{4}{|c|}{ HIV $^{-}$} \\
\hline & & PL & BL & $\mathbf{A H}$ & VH & PL & BL & $\mathbf{A H}$ & VH \\
\hline 1 & Toxoplasmosis & N & N & $\mathrm{N}$ & $\mathrm{N}$ & N & N & $\mathrm{N}$ & Toxo \\
\hline 4 & Toxoplasmosis & $\mathrm{N}$ & $\mathrm{N}$ & $\mathrm{N}$ & $\mathrm{N}$ & $N$ & $\mathrm{~N}$ & N & $\mathrm{N}$ \\
\hline 5 & Toxoplasmosis & $\mathrm{N}$ & N & $\mathrm{N}$ & $\mathrm{N}$ & CMV & CMV & $\mathrm{N}$ & $\mathrm{N}$ \\
\hline 6 & Toxoplasmosis/HSV & $\mathrm{N}$ & N & $\mathrm{N}$ & $\mathrm{N}$ & N & $\mathrm{N}$ & HSV2 & HSV2 \\
\hline 9 & Toxoplasmosis & $N$ & N & $\mathrm{N}$ & $N$ & $N$ & $\mathrm{~N}$ & N & $\mathrm{N}$ \\
\hline 10 & Toxoplasmosis & $\mathrm{N}$ & N & $\mathrm{N}$ & $\mathrm{N}$ & $\mathrm{N}$ & N & Toxo & N \\
\hline 11 & HSV & $\mathrm{N}$ & N & $\mathrm{N}$ & $\mathrm{N}$ & $\mathrm{N}$ & N & N & $\mathrm{N}$ \\
\hline 12 & Toxoplasmosis & $\mathrm{N}$ & N & $\mathrm{N}$ & N & $\mathrm{N}$ & N & $N$ & $\mathrm{~N}$ \\
\hline 13 & Toxoplasmosis & $\mathrm{N}$ & N & $\mathrm{N}$ & Toxo/HSV1 & $N$ & N & N & $N$ \\
\hline 14 & Toxoplasmosis & $\mathrm{N}$ & $\mathrm{N}$ & $\mathrm{N}$ & N & $\mathrm{N}$ & $\mathrm{N}$ & Toxo & Toxo \\
\hline 20 & Non-infectious & $N$ & $N$ & $\mathrm{~N}$ & N & $N$ & $\mathrm{~N}$ & $\mathrm{~N}$ & $\mathrm{~N}$ \\
\hline 21 & Toxoplasmosis & $\mathrm{N}$ & $\mathrm{N}$ & $\mathrm{N}$ & $\mathrm{N}$ & $\mathrm{N}$ & $\mathrm{N}$ & N & $\mathrm{N}$ \\
\hline 22 & Toxoplasmosis & $\mathrm{N}$ & $\mathrm{N}$ & $\mathrm{N}$ & $\mathrm{N}$ & $\mathrm{N}$ & $\mathrm{N}$ & N & $\mathrm{N}$ \\
\hline 23 & Toxoplasmosis/CMV & $N$ & $\mathrm{~N}$ & $\mathrm{~N}$ & $N$ & $\mathrm{~N}$ & $\mathrm{~N}$ & N & $N$ \\
\hline 24 & Syphilis & $N$ & $N$ & $\mathrm{~N}$ & $N$ & $N$ & $\mathrm{~N}$ & $\mathrm{~N}$ & $N$ \\
\hline 25 & Non-infectious & $N$ & $\mathrm{~N}$ & $N$ & $\mathrm{~N}$ & CMV & $\mathrm{N}$ & $N$ & $N$ \\
\hline 26 & Toxoplasmosis/TB & $N$ & N & $\mathrm{N}$ & $N$ & N & $\mathrm{N}$ & $N$ & N \\
\hline 27 & Toxoplasmosis & $\mathrm{N}$ & N & $\mathrm{N}$ & $\mathrm{N}$ & $\mathrm{N}$ & $\mathrm{N}$ & $N$ & Toxo \\
\hline
\end{tabular}

$\mathrm{PL}=$ plasma; $\mathrm{BL}=$ blood $\mathrm{AH}=$ aqueous humor; $\mathrm{VH}=$ vitreous humor; $\mathrm{N}=$ negative

Arora and collaborators (1999) evaluated the role of real-time PCR for detection of Mycobacterium tuberculosis in the aqueous humor samples obtained from eyes with active uveitis and showed that it can be effectively used for the diagnosis of intraocular tuberculosis $^{(21)}$. Our patients with presumed ocular tuberculosis presented negative PCR results suggesting that these patients developed uveitis for other reasons or that they had very low number of organisms in ocular fluids as well in plasma and total blood. In 2007, a study in our Institution presented one patient with presumed ocular tuberculosis that had a positive PCR reaction both in the serum and in the vitreous samples ${ }^{(22)}$

In addition, one patient, who is also $\mathrm{HIV}^{+}$, has tested positive for HSV1 infection and also by T. gondii and could have had a diagnosis of CMV due to immunocompromise because though the features of the lesion caused by the tendency for severe uveitis clinical hypothesis that toxoplasmosis is also a feature of infection in immunocompromised patients ${ }^{(23)}$.

This study indicates that clinical analysis alone may be imprecise and need further assistance such as the employment of real-time PCR in samples such as vitreous and aqueous humor to properly detect whether the uveitis is infectious or non-infectious.

Despite the difficulties of obtaining the vitreous and aqueous humor, these samples are needed to provide an accurate diagnosis which was achieved by the precise and relatively quick real-time PCR technique. The use of this technique using these samples may have contributed with accuracy of uveitis diagnosis and therefore improved outcomes for these patients.

\section{CONCLUSIONS}

In conclusion, this study showed that real-time PCR testing is a useful adjunct test for the diagnosis of infectious causes of uveitis.
Our findings disclosed that the use of real-time PCR for detecting herpes simplex virus, varicella zoster virus, T. gondii, cytomegalovirus DNA in vitreous and aqueous humors of uveitic subjects may be a valuable tool for early diagnosis. We conclude that to achieve a full diagnosis coverage regarding the etiological agent involved in uveitis, physicians should examine both aqueous and vitreous humor samples with real-time PCR.

\section{ACKNOWLEDGMENTS}

This work was supported by Fundação de Amparo a Pesquisa do Estado de São Paulo (FAPESP), Conselho Nacional de Desenvolvimento Científico e Tecnológico (CNPq) and CAPES.

\section{REFERENCES}

1. Rosenbaum JT, McDevitt HO, Guss RB, Egbert PR. Endotoxin-induced uveitis in rats as a model for human disease. Nature. 1980;286(5773):611-613.

2. Dimantas MA, Lowder C, Muccioli C. Anterior uveitis associated to systemic diseases. Arq Bras Oftalmol. 2003:66(2):235-8.

3. de Groot-Mijnes JD, de Visser L, Zuurveen S, Martinus RA, Völker R, ten Dam-van Loon NH, et al. Identification of new pathogens in the intraocular fluid of patients with uveitis. Am J Ophthalmol. 2010;150(5):628-36.

4. Harper TW, Miller D, Schiffman JC, Davis JL. Polymerase chain reaction analysis of aqueous and vitreous specimens in the diagnosis of posterior segment infectious uveitis. Am J Opthalmol. 2009;147(1):140-7.

5. Cazenave J, Cheyrou A, Aouizerate F, Poirier L, Verin P. Detection of toxoplasma in aqueous humor by using the polymerase chain reaction. Ann Biol Clin (Paris). 1992;50(5): 357-8.

6. Montoya JG, Parmley S, Liesenfeld O, Jaffe GJ, Remington JS. Use of the polymerase chain reaction for diagnosis of ocular toxoplasmosis. Ophthalmology. 1999;106(8):1554-63.

7. Fox GM, Crouse CA, Chuang E, Pflugfelder SC, Cleary TJ, Nelson SJ, et al. Detection of herpes virus DNA in vitreous and aqueous specimens by the polymerase chain reaction. Arch Ophthalmol. 1991;109(2):266-71.

8. McCann JD, Margolis TP, Wong MG, Kupperman BD, Luckie AP, Schwartz DM, et al. A sensitive and specific polymerase chain reaction-based assay for the diagnosis of cytomegalovirus retinitis. Am J Ophthalmol. 1995;120(2):219-26. 
9. Abe T, Tsuchida K, Tamai M. A comparative study of the polymerase chain reaction and local antibody production in acute retinal necrosis syndrome and cytomegalovirus retinitis. Graefes Arch Clin Exp Ophthalmol. 1996;234(7):419-24.

10. Short GA, Margolis TP, Kuppermann BD, Irvine AR, Martin DF, Chandler D. A polymerase chain reaction based assay for the diagnosis of varicella-zoster virus retinitis in patients with AIDS. Am J Ophthalmol. 1997; 123(2):157-164.

11. Dworkin LL, Gibler TM, Van Gelder RN. Real-time quantitative polymerase chain reaction diagnosis of infectious posterior uveitis. Arch Ophthalmol. 2002;120(11):1534-9.

12. Rothova A, de Boer JH, Ten Dam-van Loon NH, Postma G, de Visser L, Zuurveen SJ, et al. Usefulness of aqueous humor analysis for the diagnosis of posterior uveitis. Ophthalmology. 2008;115(2):306-11.

13. Jabs DA, Nussenblatt RB, Rosenbaum JT. Standardization of uveitis nomenclature for reporting clinical data. Results of the First International Workshop. Am J Ophthalmol. 2005;140(3):509-16.

14. Fekkar A, Bodaghi B, Touafek F, Le Hoang P, Mazier D, Paris L. Comparison of immunoblotting, calculation of the Goldmann-Witmer coefficient, and real-time PCR using aqueous humor samples for diagnosis of ocular toxoplasmosis. J Clin Microbiol. 2008; 46(6):1965-7

15. Turno-Krecicka A, Misiuk-Hojlo M, Grzybowski A, Oficjalska-Mlynczak J, JakubowskaKopacz M, Jurowska-Liput J. Early vitrectomy and diagnostic testing in severe infectious posterior uveitis and endophthalmitis. Med Sci Monit. 2010;16(6):CR296-300.
16. Nogueira ML, Siqueira RC, Freitas N, Amorim JB, Bonjardim CA, Ferreira PC, et al. Detection of herpesvirus DNA by the polymerase chain reaction (PCR) in vitreous samples from patients with necrotising retinitis. Clin Pathol. 2001;54(2):103-6.

17. de Boer JH, Verhagen C, Bruinenberg M, Rothova A, de Jong PT, Baarsma GS, et al. Serologic and polymerase chain reaction analysis of intraocular fluids in the diagnosis of infectious uveitis. Am J Ophthalmol. 1996:121(6):650-8.

18. Westeneng AC, Rothova A, de Boer JH, de Groot-Mijnes JD. Infectious uveitis in immunocompromised patients and the diagnostic value of polymerase chain reaction and Goldmann-Witmer coefficient in aqueous analysis. Am J Ophthalmol. 2007:144(5):781-5.

19. Nguyen QD, Kempen JH, Boltona SG, Dunn JP, Jabs DA, Immune recovery uveitis in patients with AIDS and cytomegalovirus retinitis after highly active antiretroviral therapy, Am J Ophthalmol. 2000; 129(5): 634-9.

20. Markomichelakis NN, Canakis C, Zafirakis P, Marakis T, Mallias I, Theodossiadis G. Cytomegalovirus as a cause of anterior uveitis with sectoral iris atrophy. Ophthalmology.2002; 109(5):879-82

21. Arora SK, Gupta V, Gupta A, Bambery P, Kapoor GS, Sehgal S. Diagnostic efficacy of polymerase chain reaction in granulomatous uveitis. Tuber Lung Dis. 1999;79(4):229-33.

22. Matos K, Muccioli C, Belfort Junior R, Rizzo LV. Correlation between clinical diagnosis and PCR analysis of serum, aqueous, and vitreous samples in patients with inflammatory eye disease. Arq Bras Oftalmol. 2007;70(1):109-14.

23. Cunningham ET. Uveitis in HIV positive patients Br J Ophthalmol. 2000;84(3):233-6

\section{$37^{\circ}$ Congresso da Sociedade Brasileira de Retina e Vítreo}

12 a 14 de abril de 2012

Hotel Windsor

Barra da Tijuca - Rio de Janeiro - RJ

Informações:

Site: http://www.interevent.com.br/ E-mail:retina2012@interevent.com.br
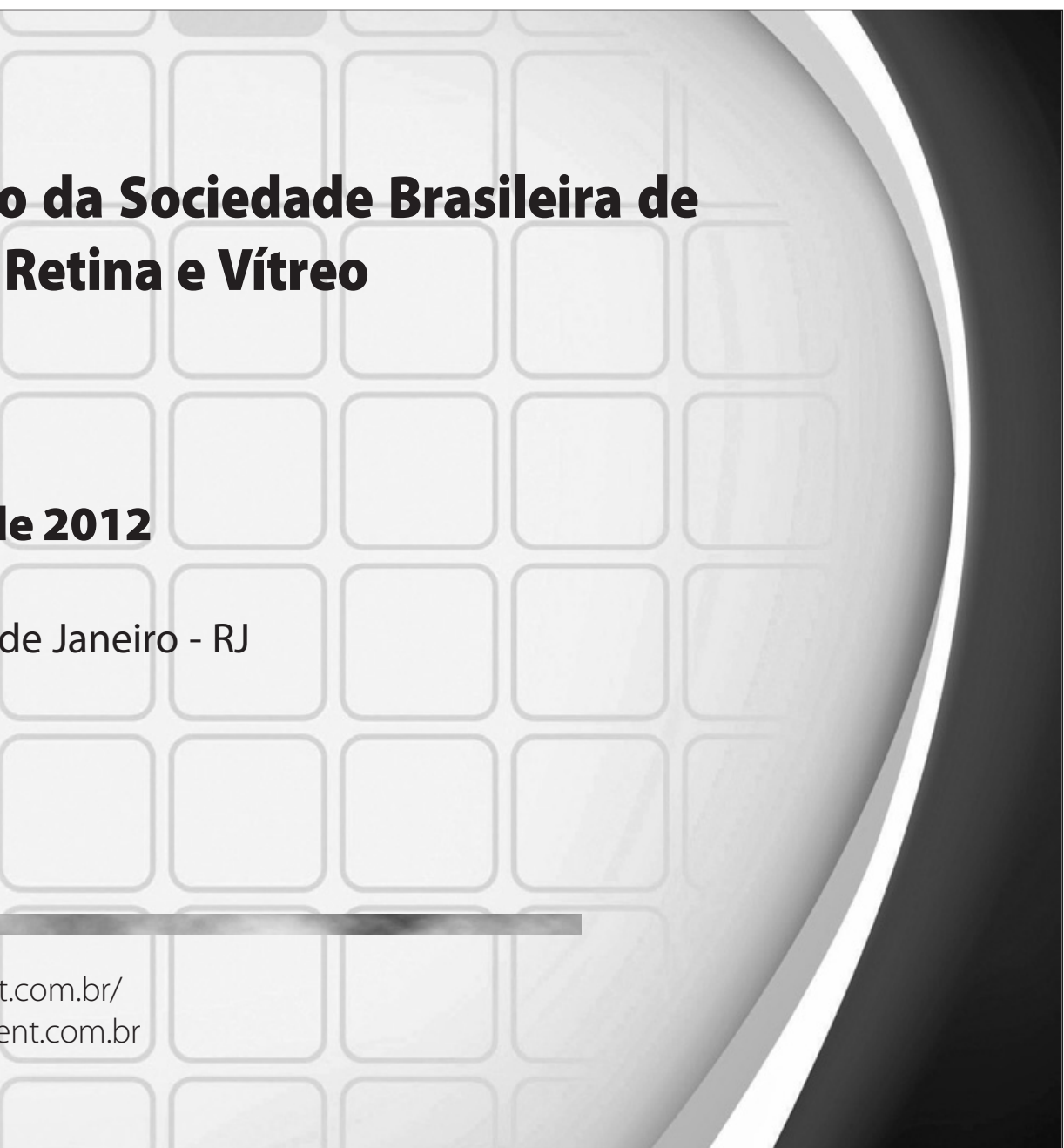